\title{
Editorial
}

\section{Expanding the Value of CLIL: Perspectives from Primary to Higher Education}

Expandiendo el valor de AICLE: perspectivas desde primaria hasta enseñanza superior

Aumentando o valor do CLIL: perspectivas do ensino primário ao superior

Jermaine S. McDougald https://orcid.org/0000-0002-2558-5178 Universidad de La Sabana jermaine.mcdougaldı@unisabana.edu.co Claudia Patricia Alvarez-Ayure
https://orcid.org/o0oo-000I-7425-6437
Universidad de La Sabana
claudiap.alvarez@unisabana.edu.co

To reference this article (APA) / Para citar este artículo (APA) / Para citar este artigo (APA) McDougald, J. S. \& Álvarez-Ayure, C. P. (2020). Expanding the Value of CLIL: Perspectives from Primary to Higher Education. Latin American Journal of Content \& Language Integrated Learning, 13(2), 155-162. https://doi.org/10.5294/laclil.2020.13.2.1 


\section{Introduction}

Education continues to evolve as the world in which we live changes, and learners are in constant need of skills and competencies to successfully manage the information provided to them in the $21^{\text {st }}$ century (Kowalczuk-Walêdziak et al., 2018). Approaches like Content and Language Integrated Learning (CLIL), English as a Medium of Instruction (EMI), and even Content-Based Instruction (CBI) all provide English language learners (ELL) with tools, strategies, and opportunities in education for real-world challenges and obstacles (Graham et al., 2018; Taillefer, 2013), where learners can make sense of the information presented to them, while collaborating and using that information for real-world use and not just for artificial classroom tasks and assignments. Nowadays, educational programs have to prepare society for jobs, careers, and skill sets that do not exist yet but which lead to shifts in society that are shaped by both the economy and fast-increasing technology at hand throughout the world.

Approaches like CLIL and EMI are spreading at a faster rate across all educational levels (from Preschool to Higher Education) across the globe (Banegas et al., 2020; Graham et al., 2018; Lin, 2015; Pérez-Cañado, 2016; Yang, 2017), bringing a refreshed sense of understanding the needs learners have and using context-oriented solutions, along with first-rate approaches to education to improve the teaching and learning process. CLIL has gone from a buzzword or a cliché term to refer to bilingual education, to the center of educational debates as a viable option for education, and not just language learning. These debates are supported by research that continues to highlight the benefits of integrating content and language in bi/multilingual educational contexts, (Várkuti, 2010; Corrales, Rey, \& Escamilla, 2016) where the CLIL approach relies on the inherent connections that exist between language and subject-specific content, contributing to a more natural and realistic pedagogy. Furthermore, such a pedagogy represents a true paradigm shift and requires not just more teacher training or professional development but training that is targeted at preparing educators to participate in making this shift a reality (Jalo \& Pérez-Albizú, 2014; Penprase, 2018; Youssef, 2014). Adopting a CLIL or EMI approach 
is far from a quick fix for our educational system; however, it is a fresh approach to overall learning that can help learners become true 21st-century citizens, prepared to both "think globally" and "act locally" (McDougald, 2015, p. 38).

\section{Expansion of Content and Language Learning Across the Globe}

CLIL continues to expand across the globe because it provides a realistic solution to education as we know it. However, this expansion does not come alone, and isolated teacher training programs with no clear direction or objective are only at the beginning, which is why there must be a premise for planning what that core curriculum should involve at the different levels of education. Stakeholders, practitioners, and researchers alike need to estimate the changes in the operating environments as well as by analyzing the current state of the art (local, regional, national) regarding teaching, education, and bi/multilingualism while incorporating findings from research, evaluations, and development projects. The former, especially the research findings, provide decision makers with contextualized realistic data on how to move forward, making educated decisions regarding the integration of content and language. This expansion is in line with globalization, impacting both positively and negatively education across the globe (Goris et al., 2019) where the information gap may get bigger from developed countries as opposed to developing countries, where access to resources is often the main reason that limits access to first-hand information and opportunities. Nevertheless, there are several areas where globalization has made a difference in how educators view their classrooms and learners (Gupta, 2017). There is more emphasis on collaborating and working in teams, being able to cross borders at any given time, as a result of increased communication and Information and Communications Technology (ICT) capabilities (Binkley et al., 2012; Trilling \& Fadel, 2012), while helping learners to become more open-minded, with higher levels of intercultural competences. Globalizing education also helps to break down cultural barriers that would otherwise be an issue in 
the classroom; however, like ideas are grouped, global issues are being resolved collectively and development as a whole brings about local solutions at a global scale through that shared knowledge. Finally, but possibly most essential, CLIL and EMI provide students with a milieu for them to critically engage in today's cultural and contextual issues, an added value that, in turn, affords individual involvement, learner decision making and authenticity to the learning of content through the use of a foreign language.

This issue of the journal is a clear indication of how research across the globe between the Americas, Asia, Europe, and the Middle East (The United States of America, Taiwan, Iran, Mexico, Turkey, Colombia, Puerto Rico, and Italy) continues to report on the diversity in integrating content and language in bi/multilingual teaching environments. Educators and interdisciplinary research approaches are crucial in achieving a more comprehensible understanding of the complex phenomena that learners are facing across the globe keeping the CLIL debate at forefront of bi/multilingual education.

\section{In this issue}

The articles discussed in this issue of the Latin American Journal of Content and Language Integrated Learning (LACLIL, Vol. 13, No. 2, 2020) concern children's literature and CLIL, reading comprehension in EFL, language objectives in lesson plans and assessment in content-based instruction, English as a medium of instruction and the internationalization of higher education, teacher's and student's beliefs on the use of Spanish in an advanced English classroom and the implementation of CLIL in the field of pharmacology.

The issue begins with a systematic review of the use of children's literature in the EFL classroom supported by the CLIL framework: content, communication, cognition, and culture. Graham Matthews and Eslami (2020), revealed that, although the use of children's literature can facilitate students' learning in terms of content, cognition and culture, the use of this type of literature and its value in the CLIL classroom in Taiwan is still mostly absent from the researchers' and practitioners' research agendas. 
Furthermore, an investigation by Bahrami and Rahimy (2020) on the impact of an analysis matrix summarization technique on the reading comprehension of a group of Iranian higher education students, claims that visual outlines facilitate students' text comprehension as these contribute to the organization of the main ideas, represent a guideline to create written summaries and enhance reading comprehension and retention.

The study by Arias de la Cruz (2020) documents the challenges that three Mexican students encountered while participating in a Content-based Instruction (CBI) module from a Master's program in English Language Teaching (ELT). The author expressed the difficulties in writing content and language objectives for CBI lessons. In the case of content-related objectives, the salient difficulty was their lack of clarity whereas in the case of language-related objectives, the verbs employed in their formulation required students to exercise only their lower-order cognitive skills.

An evaluation of the assessment component of a customized CBI program by Isik (2020) provides findings on the attitudes of the students and the teachers towards the assessment component of a customized CLIL course in an EFL program at the tertiary level in Turkey. The results indicate that both the students and the teachers developed positive attitudes towards the assessment component of CLIL. A component found to be, in turn, an adequate tool for the integrated assessment of content and language.

Perceptions and attitudes can also be found in Tejada-Sanchez and Molina-Naar's (2020) findings related to the implementation of EMI at a Colombian university as part of an internationalization process. To this end, the participants' perceptions associated with their imaginaries, identities, experiences, and obligations in relation to the English language are reported. The study suggests that as a sustainable strategy, EMI requires contextual awareness and articulation amongst its participants.

Furthermore, Puerto Rican teachers' and students beliefs towards the use of Spanish in an Advanced English class are portrayed in a study by Mari and Carroll (2020). Their article documents the rationale of many English teachers on the island to use Spanish in the English classroom as they sought to make their teaching more comprehensible. 
Although the students of both private and public schools suggest caution towards the excessive use of Spanish in the English classroom, the findings suggest that many English teachers consciously or unconsciously adopt a translanguaging approach that needs to be assessed critically in regards to the FL (foreign language) proficiency and the level of confidence of the students in their classrooms.

The last article explores the perception of a group of Italian pharmacology students who participated in a partial piloting of a CLIL-oriented class approach. Filice (2020) reveals positive student views on the organization of the pilot course and provides suggestions to teachers and stake holders planning to structure future CLIL programs.

In closing, we would like to express our heartfelt gratitude to our readership, authors, peer evaluators and editorial team who have contributed to the creation of a venue for young Latin American and world-wide researchers. We are sure that the journal has empowered practitioners, researchers, and stake holders to continue joining efforts to procure a high-quality education and innovation in their fields.

It has been a privilege to serve the journal and its readership as Editor and Associate Editor. We are sure that the journal will continue to prosper under the direction of Dr. Carl E. Anderson, who will act from the start of 2021 as the new editor to the journal. We wish him all sorts of success.

\section{References}

Arias, A. (2020). Teachers' challenges to write content and language objectives for CBI lesson plans at a Mexican university. Latin American Journal of Content \& Language Integrated Learning, 13(2), 215-240. https:// doi.org/10.5294/laclil.2020.13.2.4

Bahrami, S., \& Rahimy, R. (2020). Investigating impact of analysis matrix summarization technique on Iranian university students' reading comprehension enhancement. Latin American Journal of Content \& Language Integrated Learning, 13(2), 191-214. https://doi.org/10.5294/ laclil.2020.13.2.3

Banegas, D. L., Poole, P. M., \& Corrales, K. A. (2020). Content and language integrated learning in Latin America 2008-2018: Ten years of 
research and practice. Studies in Second Language Learning and Teaching, 10(2), 283-305.

Binkley, M., Erstad, O., Herman, J., Raizen, S., Ripley, M., Miller-Ricci, M., \& Rumble, M. (2012). Defining twenty-first century skills. In Griffin P., McGaw B., Care E. (Eds.), Assessment and Teaching of 21st Century Skills (Vol. 9789400723, pp. 17-66). Springer. https://doi.org/10.1007/97894-007-2324-5_2

Corrales, K. A., Rey, L. A., \& Escamilla, N. S. (2016). Is EMI Enough? Perceptions from university professors and students. Latin American Journal of Content \& Language Integrated Learning, 9(2), 17-36. https://doi. org/10.5294/laclil.2016.9.2.6

Filice, S. (2020). CLIL in pharmacology: Enabling student voice. Latin American Journal of Content \& Language Integrated Learning, 13(2), 313-338. https://doi.org/10.5294/laclil.2020.13.2.7

Goris, J., Denessen, E., \& Verhoeven, L. (2019). The contribution of CLIL to learners' international orientation and EFL confidence. The Language Learning Journal, 47(2), 246-256. https://doi.org/10.1080/09571 736.2016.1275034

Graham, K. M., Matthews, S. D., \& Eslami, Z. R. (2020). Using children's literature to teach the 4Cs of CLIL: A systematic review of EFL studies. Latin American Journal of Content \& Language Integrated Learning, 13(2), 163-190. https://doi.org/10.5294/laclil.2020.13.2.2

Graham, K. M., Choi, Y., Davoodi, A., Razmeh, S., \& Dixon, L. Q. (2018). Language and content outcomes of CLIL and EMI: A systematic review. Latin American Journal of Content \& Language Integrated Learning, 11(1), 19-38. https://doi.org/10.5294/laclil.2018.11.1.2

Gupta, P. (2017). Impact of globalization in education. https://edtechreview.in/ news/2730-globalization-in-education

Işılk, A. (2020). How effective is the assessment component of a customized CLIL program? Latin American Journal of Content \& Language Integrated Learning, 13(2), 241-287. https://doi.org/10.5294/laclil.2020.13.2.5

Jalo, M. L., \& Pérez Albizú, C. (2014). CLIL: The approach for the future? Memoria Académica.

Kowalczuk-Walêdziak, M., Korzeniecka-Bondar, A., Danilewicz, W., \& Lauwers, G. (Eds.). (2019). Rethinking Teacher Education for the 21st Century: Trends, Challenges and New Directions. Opladen; Berlin; Toronto: Verlag Barbara Budrich, (pp 12-24). https://doi.org/10.2307/j.ctvpb3xhh 
Lin, A. M. Y. (2015). Conceptualising the potential role of L1 in CLIL. Language, Culture and Curriculum, 28(1), 74-89. https://doi.org/10.1080/07 908318.2014.1000926

Mari, V., \& Carrol, K. S. (2020). Puerto Rican teachers' and students' beliefs toward Spanish use in the classroom. Latin American Journal of Content \& Language Integrated Learning, 13(2), 289-311. https://doi. org/10.5294/laclil.2020.13.2.6

McDougald, J. S. (2015). Teachers' attitudes, perceptions and experiences in CLIL: A look at content and language. Colombian Applied Linguistics Journal, 17(1), 25-41. https://doi.org/10.14483/udistrital.jour. calj.2015.1.a02

Penprase, B. E. (2018). The fourth industrial revolution and higher education. In N. Gleason (Ed.), Higher Education in the Era of the Fourth Industrial Revolution (pp. 207-228). Palgrave Macmillan, Singapore. https:// doi.org/10.1007/978-981-13-0194-0_9

Pérez-Cañado, M. L. (2016). Are teachers ready for CLIL? Evidence from a European study. European Journal of Teacher Education, 39(2), 202-221. https://doi.org/10.1080/02619768.2016.1138104

Taillefer, G. (2013). CLIL in higher education: the (perfect?) crossroads of ESP and didactic reflection. Multiplicités Des Approches En Anglais de Spécialité, 63(2013), 31-53. https://doi.org/10.4000/asp.3290

Tejada-Sanchez, I., \& Molina-Naar, M. (2020). English medium instruction and the internationalization of higher education in Latin America: A case study from a Colombian university. Latin American Journal of Content \& Language Integrated Learning, 13(2), 339-367. https://doi. org/10.5294/laclil.2020.13.2.8

Trilling, B., \& Fadel, C. (2012). 21st Century Skills Learning for Life in Our Times (1st ed.). John Wiley and Sons Inc.

Várkuti, A. (2010). Linguistic benefits of the CLIL approach: Measuring linguistic competences. International CLIL Research Journal, 1(3), 67-79.

Yang, W. (2017). Tuning university undergraduates for high mobility and employability under the content and language integrated learning approach. International Journal of Bilingual Education and Bilingualism, 20(6), 607-624, https://doi.org/10.1080/13670050.2015.1061474

Youssef, L. (2014). Globalisation and higher education: from within-border to cross-border. Open Learning: The Journal of Open, Distance and e-Learning, 29(2), 100-115. https://doi.org/10.1080/02680513.2014.932686 